\title{
Prevalence, burden, and clinical management of migraine in China, Japan, and South Korea: a comprehensive review of the literature
}

Takao Takeshima', Qi Wan², Yanlei Zhang ${ }^{3}$, Mika Komori ${ }^{4}$, Serina Stretton ${ }^{5}$, Narayan Rajan ${ }^{6}$, Tamas Treuer ${ }^{7}$ and Kaname Ueda ${ }^{4^{*}}$ (D)

\begin{abstract}
Background: The objective of this review was to determine the unmet needs for migraine in East Asian adults and children.

Methods: We searched MEDLINE and EMBASE (January 1, 1988 to January 14, 2019). Studies reporting the prevalence, humanistic and economic burden, and clinical management of migraine in China (including Hong Kong and Taiwan), Japan, and South Korea were included. Studies conducted before 1988 (before the International Headache Society [IHS] first edition of the International Classification of Headache Disorders) were not included.

Results: We retrieved 1337 publications and 41 met the inclusion criteria (28 from China, 7 from Japan, and 6 from South Korea). The 1-year prevalence of migraine (IHS criteria) among adults ranged from $6.0 \%$ to $14.3 \%$. Peak prevalence ranged from $11 \%$ to $20 \%$ for women and $3 \%$ to $8 \%$ for men (30- to 49-year-olds). For children, prevalence of migraine increased with age. Information on the economic burden and clinical management of migraine was limited, particularly for children. When reported, migraine was significantly associated with high levels of disability and negative effects on quality of life. Studies suggested low levels of disease awareness/diagnosis within each country. Of individuals with migraine from China, 52.9\% to $68.6 \%$ had consulted a physician previously, $37.2 \%$ to $52.7 \%$ diagnosed with headache had not been diagnosed with migraine previously, and $13.5 \%$ to $18 \%$ had been diagnosed with migraine previously. Of individuals with migraine from Japan, 59.4\% to $71.8 \%$ had never consulted a physician previously, $1.3 \%$ to $7.3 \%$ regularly consulted physicians for their headache, and only $11.6 \%$ of individuals with migraine were aware that they had migraine. In addition, studies suggested that over-the-counter medication use was high and prescription medication use was low in each country.

Conclusions: This review suggests that there are unmet needs for migraine in terms of sufficient and appropriate diagnosis, and better management and therapies for treatment of migraine in East Asia. The findings are limited by a lack of recent information and significant gaps in the literature. More recent, population-based studies assessing disease burden and clinical management of migraine are needed to confirm unmet needs for migraine across East Asia.
\end{abstract}

Keywords: Burden, China, Cost of illness, Epidemiology, Far East, Hong Kong, Japan, Korea, Medical economics, Migraine disorders, Prevalence, Quality of life, Taiwan

\footnotetext{
* Correspondence: ueda_kaname@lilly.com

${ }^{4}$ Medicine Development Unit-Japan, Eli Lilly Japan K.K., 5-1-28, Isogamidori,

chuo-ku, Kobe 651-0086, Japan

Full list of author information is available at the end of the article
}

(c) The Author(s). 2019 Open Access This article is distributed under the terms of the Creative Commons Attribution 4.0 International License (http://creativecommons.org/licenses/by/4.0/), which permits unrestricted use, distribution, and reproduction in any medium, provided you give appropriate credit to the original author(s) and the source, provide a link to the Creative Commons license, and indicate if changes were made. 


\section{Introduction}

Migraine is a disabling primary headache disorder that places an enormous burden on patients and society [17]. The impact of migraine extends beyond the physical pain of a migraine attack and can have substantial effects on multiple aspects of an individual's life, including day-to-day functioning [7-9]. Findings from the Global Burden of Disease Study found migraine to be the second highest cause of years lost due to disability, interfering significantly with occupational, educational, household, family, and social responsibilities [10], and the second highest contributor to neurological disease burden, after stroke [11].

Most data on migraine burden worldwide are derived from epidemiological surveys conducted mostly in the United States and Europe [1-3, 5, 6, 12-14]. However, disease burden can vary significantly by geography and ethnicity, particularly for chronic conditions such as migraine in which pain is a major contributor to disability [15]. Two reviews on migraine and headache prevalence have been conducted in the Asia-Pacific region, including countries from East Asia, Southeast Asia, and West Asia $[16,17]$. These reviews were focused on the prevalence of chronic migraine and chronic daily headache, and on headache disorders across multiple countries, with little information on migraine-related burden.

The objective of this comprehensive literature review of the evidence related to the prevalence, burden, and clinical management of migraine in East Asia (China, Japan, and South Korea) was to determine the unmet needs for migraine in both adults and children. The key outcomes were prevalence, disease burden (humanistic or economic), and clinical management of migraine, including health care utilization and clinical practice patterns.

\section{Materials and methods}

\section{Data sources and search terms}

The following online databases were searched: MEDLINE via Ovid (1988 to January 14, 2019), EMBASE via Ovid (January 1, 1988 to January 14, 2019). Search strategies were developed by an author (SS), adapted for each database, and included keywords (Medical Subject Heading or EMTREE) and free-text terms for the following subjects: Migraine disorders or chronic daily headache, China (including Taiwan and Hong Kong), South Korea, and Japan. Because small numbers of publications were retrieved with these terms, specific terms for disease burden were not included in the electronic search strategy. For each database, electronic searches were limited to studies conducted in humans.

\section{Eligibility criteria}

Publications were included if they reported on participants with migraine from China (including Hong Kong and Taiwan), South Korea, or Japan. There were no restrictions on the definition of migraine, age group included, or language of publication. All studies were to include at least one of the following outcomes of migraine: prevalence, humanistic burden (all reported measures of health-related quality of life [HRQoL], migraine-related disability, and measures of the impact of migraine on aspects of daily living and social activities), economic burden (work-related productivity, direct and indirect medical costs), and clinical management (health care utilization, clinical practice patterns). Randomized and nonrandomized clinical studies, longterm follow-up studies, and prospective and retrospective observational studies were included for all outcomes except prevalence. For studies reporting prevalence, only population-based studies were included.

Publications were excluded for the following reasons: studies conducted or published before 1988 (before the International Headache Society [IHS] first edition of the International Classification of Headache Disorders [ICHD-1]) [18] and before the availability of triptans, which were the first disease-specific medications for acute treatment of migraine); reported on participants with mixed headache types in which data for those with migraine were not reported separately; the race/ethnicity of the study population was not reported; populations of interest were not reported separately in studies on mixed populations, or populations of interest resided in other countries; were preclinical, animal, and other nonclinical experimental studies; were case studies or series, review articles, letters to the editor, consensus papers or guidelines, and congress abstracts; reported on duplicate data; reported on outcomes for fewer than 30 participants; or did not report on the prespecified outcomes. Reference lists from relevant systematic reviews and meta-analyses that were retrieved in the search strategy were screened manually to identify publications not retrieved by the literature search strategies.

\section{Screening and data extraction}

Searches were collated using bibliographic management software. An initial screen of the title and abstract of each publication retrieved from the search strategy was conducted by one author (SS) to remove duplicate publications and identify potential publications that met the criteria for migraine and eligible country. Inclusion of each potential publication was then confirmed after a review of the full text to identify publications reporting one or more of the following eligible outcomes: prevalence of migraine, humanistic burden, economic burden, and clinical management as described above. All authors were consulted in instances when inclusion was uncertain, and authors reviewed and approved the final list of articles identified for inclusion in the review. 
One author (SS) extracted all data into prespecified data tables. A second independent reviewer (non-author) checked all extracted data, and any disagreements were resolved by consensus. The data extracted included study characteristics, population characteristics, criteria for migraine diagnosis, prevalence of migraine, outcomes measuring or describing migraine burden (humanistic, work-related productivity, indirect and direct medical costs), health care utilization, and clinical practice patterns.

\section{Results}

\section{Literature search output}

A total of 1337 publications were retrieved: 1336 by electronic searching and 1 by hand searching (Fig. 1). The 3 main reasons for exclusion were duplicate publications/publications reporting duplicate data, treatment outcomes only, and no relevant outcomes. A total of 41 publications were identified for inclusion: 28 from China, including China mainland [19-30], Hong Kong [31, 32], and Taiwan [33-46], 7 from Japan [47-53], and 6 from South Korea [54-59]. The included publications were published between 1995 and 2018 and reported on studies conducted between 1993 and 2018. Only 4 studies were conducted within the last 5 years.
Prevalence of migraine: population-based studies There were 23 population-based studies (24 publications) reporting the prevalence of migraine from a specified geographic area or community (see Additional file 1 ); 11 were in adults, 2 in elderly adults ( $\geq 60$ years), 2 in young adults (university students), and 8 in schoolchildren and/or adolescents.

Most of the population-based studies identified migraine according to IHS [18] criteria (ICHD-1, ICHD-II, or ICHD-III $\beta$ ) (see Additional file 1). Two studies used modified migraine criteria and included attacks of 2- to 4-h duration [43, 51]. Shorter headache durations in subjects who fulfilled all other IHS criteria were used in these studies because almost all subjects took medication for their headache or slept to alleviate headache and, therefore, it was not possible to confirm durations longer than $4 \mathrm{~h}[43,51]$. One study included migrainous headache not fulfilling ICHD migraine criteria [59], and 3 studies used the Chinese version of the ID Migraine Screener $[19,26,27]$ to diagnose migraine.

\section{Prevalence of migraine in adults}

Of the studies reporting prevalence of migraine according to IHS criteria, the 1-year prevalence among nonelderly adults ranged from $6.0 \%$ in Japan to $14.3 \%$ in mainland China (see Additional file 1). Crude estimates

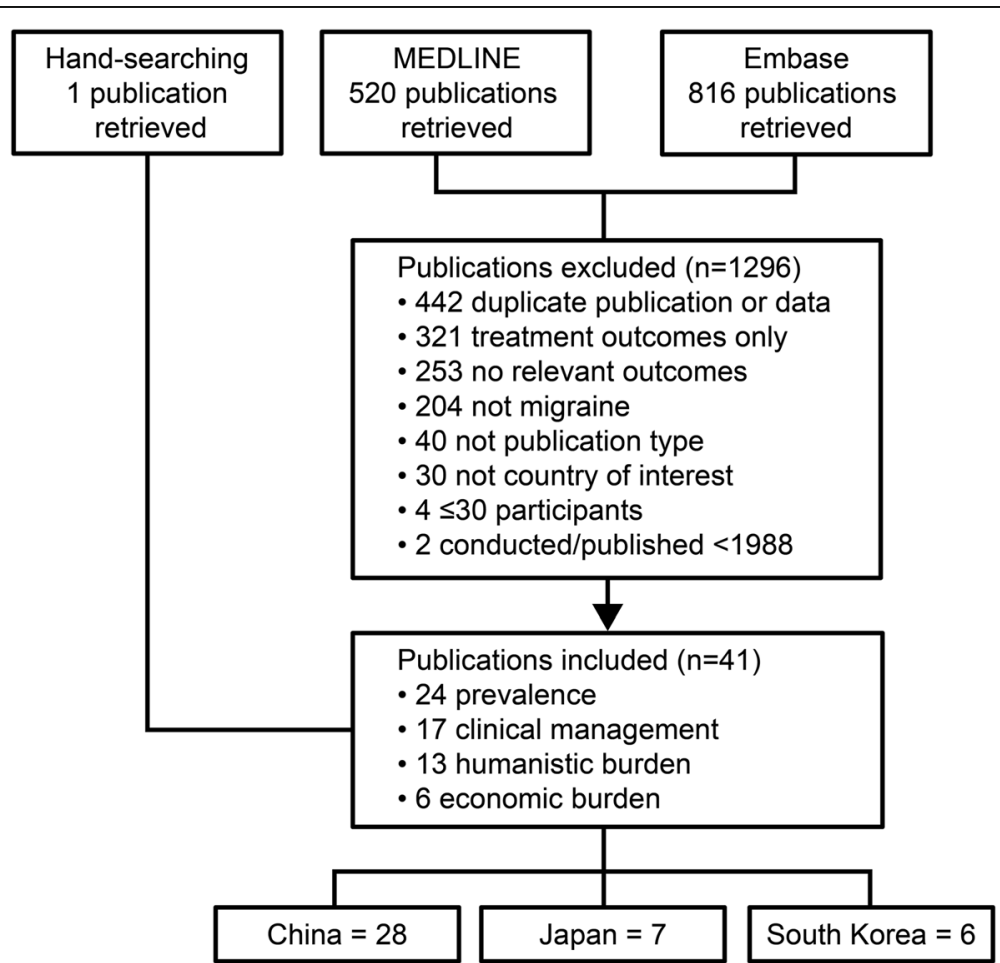

Fig. 1 Publication flow Note: publications were excluded for 1 reason but may have met $>1$ exclusion criterion; most included publications reported outcomes for $\geq 2$ topics. 
of prevalence ranged from $4.7 \%$ in Hong Kong to $10.5 \%$ in an ethnic minority group in mainland China. Although there was variation in peak prevalence among the studies and between countries, the peak prevalence among non-elderly adults ranged from $7 \%$ among 40 - to 49 -year-olds in South Korea to $13.5 \%$ among 30 - to 34 year-olds in Taiwan and was highest for women (Fig. 2; see Additional file 1). Across all studies in non-elderly adults, the peak prevalence of migraine according to IHS criteria ranged from $11 \%$ to $20 \%$ for women and from $2.8 \%$ to $8.3 \%$ for men, most typically among 30 - to 49 year-olds (see Additional file 1). The peak prevalence in elderly adults was $1.2 \%$ and $4.1 \%$ among 60 - to 69 -yearolds from China mainland and Taiwan, respectively (see Additional file 1). There appeared to be no change over time (from 1993 to 2013) in the peak prevalence of migraine among adult men or women (data not shown).

\section{Prevalence of migraine in children}

Comparisons of schoolchildren by age or over time suggested that the prevalence of migraine increased with increasing age $[36,58]$ (see Additional file 1). The prevalence of migraine from a study in Taiwan was $4.8 \%$, $7.1 \%$, and $8.4 \%$ for ages 13,14 , and 15 years, respectively [36], and from a study in South Korea was $4.9 \%, ~ 9 \%$, and $14.2 \%$ for age ranges 6 to 12,13 to 15 , and 16 to 18 years, respectively [58]. The prevalence of migraine (ICHD-III $\beta$ ) among junior and senior school students in Japan was $3.5 \%$ for 6 - to 12 -year-olds and $5.0 \%$ for 12 to 15 -year-olds [48]. When reported, the prevalence of migraine was consistently higher for girls than boys [36, $40,47,58]$. The peak prevalence of migraine among children up to 15 years of age was lower compared with the prevalence in adults, but higher than in elderly adults (Fig. 2). However, comparisons of peak prevalence among children are difficult because of the different age groups enrolled in each study, which for some studies overlapped with the adult populations (see Additional file 1).

\section{Humanistic burden of migraine in adults}

There was limited information on the burden of migraine in East Asia (Fig. 3). A total of 9 studies (11 publications) reporting the humanistic burden of migraine in adults were retrieved (Table 1): 5 population-based studies and 4 cross-sectional cohort studies of patients at headache clinics. The instruments used to assess humanistic burden included HRQoL instruments such as the EuroQoL-5 Dimensions (EQ-5D) questionnaire, the 36item Short-Form health survey (SF-36), and the World Health Organization QoL-8 questionnaire (WHOQoL-8) $[27,29,42,46]$. Migraine-related changes in QoL were assessed using country-specific versions of the Migraine Disability Assessment Questionnaire [MIDAS], the Migraine-Specific QoL [MSQ] Questionnaire, and the Headache Impact Test [HIT-6] [34, 46, 49, 55-57]. In addition, several studies reported on other non-specified instruments to assess effects of migraine on aspects of daily living $[51,55-57,59]$.

When reported, the humanistic burden of migraine was substantial, suggesting that there are unmet needs for improved detection and treatment of migraine across East Asia (Table 1). Regression analysis of patients with chronic and episodic migraine from Taiwan showed chronic migraine to be significantly associated with higher levels of disability (MIDAS), lower MSQ scores (role function-restrictive, role function-preventive, and emotional function), and lower EQ-5D scores [46] than for episodic migraine. In addition, assessments of HRQoL conducted in China showed that migraine had negative effects on almost all SF-36 domains [27, 42]
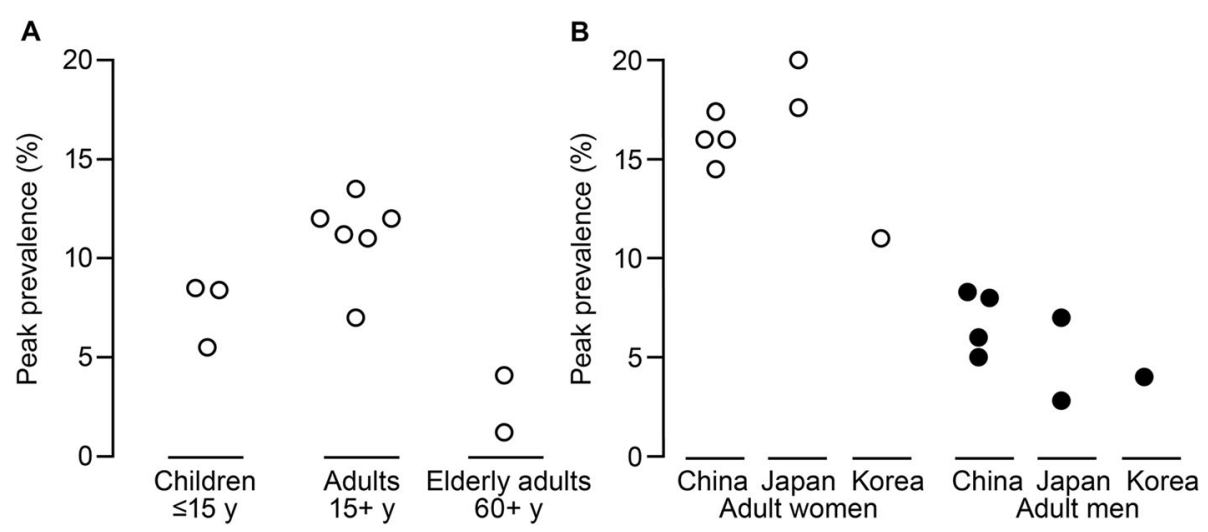

Fig. 2 Publications reporting peak prevalence (A) by age groups and (B) by country. Data in (A) were derived as follows: children [31, 36, 40], adults $[20,23,27,29,43,56]$, and elderly adults $[30,45]$. Note, because of the age groups enrolled in each study, there was overlap in populations among the children, adult, and elderly adult categories. The prevalence of migraine in children aged 16-18 years from Roh et al. 2012 (14.2\%) [58] is not included because of the overlap in age with adults. Data in (B) were derived as follows: China [20, 27, 29, 43], Japan [51, 53], and South Korea [56]. Roh et al. 1998 [59] used a non-standard definition of migraine for adults in South Korea and is not reported in panels A or B 


Korea
Kumanistic
burden

and that the SF-36 domains most significantly (linear regression, $p<0.05)$ affected were role-physical, roleemotional, bodily pain, physical functioning, and general health domains [27]. In addition, WHOQoL-8 total and domain scores were significantly $(t$ test, $p<0.05)$ lower for patients with migraine compared with those without headache [29]. The domains most negatively affected were health level, daily life ability, and daily life energy.

In general, migraine was associated with moderate to severe levels of disability in approximately one-third of individuals from population-based studies in Japan and South Korea [51, 55-57, 59] (Table 1). In addition, mean MIDAS scores from studies conducted in China and Japan [34, 46, 49] indicated severe levels of disability among many patients attending headache clinics for migraine.

\section{Economic burden of migraine in adults}

Very few studies on economic burden were retrieved (Table 2). Of the 6 studies retrieved, 3 provided an estimate of the direct or indirect medical costs of migraine or of costs associated with migraine work-related disability $[29,33,38]$, with all suggesting that the economic impact of migraine was substantial at the time the studies were conducted.

From the population-based study conducted in mainland China in 2009, direct costs for out-of-pocket expenses for diagnosis and treatment per person affected year was estimated to be Chinese yuan renminbi (CNY) 729 , resulting in direct costs per year of CNY 58.0 billion
(United States dollars [USD] 8.4 billion). Individuals with migraine reported an average of 3 missed work or housework days and an average of 4 impaired work days and 9 impaired housework days over a 3-month period, resulting in an estimated CNY 273.7 billion (USD 39.4 billion) in indirect costs arising from migraine-related lost productivity. Combined, the total annual cost of migraine per year was estimated to be CNY 331.7 billion (USD 47.8 billion) [29].

Findings from a retrospective case-control analysis from Taiwan compared total drug and medical costs of patients with refractory migraine and with other migraine, and patients with refractory migraine and without migraine [38]. Health care utilization (outpatient visits, emergency visits, hospital admission, and length of stay) was significantly greater in patients with refractory migraine compared with other migraine types. The mean total annual medical costs per person with refractory migraine and other migraine were estimated at New Taiwan Dollars (NTD) 54,678 (USD 1682) and NTD 38,397 (USD 1181), respectively. Health care utilization was also significantly greater in patients with refractory migraine compared with patients without migraine. The mean total medical costs per person were NTD 26,817 (USD 825) and NTD 57,932 (USD 1783), respectively.

Findings from a population-based study conducted in Taiwan in 1997-1998 estimated that migraine was responsible for an annual cost of NTD 4873 (USD 149) per person and a total annual cost of NTD 4.6 billion 
Table 1 Studies reporting humanistic burden of migraine

\begin{tabular}{|c|c|c|c|c|c|}
\hline Citation & $\begin{array}{l}\text { Country/ } \\
\text { region }\end{array}$ & $\begin{array}{l}\text { Study design } \\
\text { Study dates } \\
\text { Migraine criteria }\end{array}$ & $\begin{array}{l}\text { Migraine } \\
\text { criteria }\end{array}$ & $\begin{array}{l}\text { Migraine (n) } \\
\text { Age, y } \\
\% \mathrm{~F}\end{array}$ & Main findings for participants with migraine \\
\hline Yu, 2012 [29] & $\begin{array}{l}\text { China / } \\
\text { Mainland }\end{array}$ & $\begin{array}{l}\text { Population-based } \\
2009\end{array}$ & ICHD-II & $\begin{array}{l}469 \\
\text { Mean } 46.2 \text { y } \\
67.6 \mathrm{~F}\end{array}$ & $\begin{array}{l}\text { World Health Organization QoL-8 (migraine }[n=464] \\
\text { vs no headache; } P<0.05 \text { for all comparisons): } \\
\text { - Total score } 25.7 \text { vs } 27.9 \\
\text { - Life quality } 3.2 \text { vs } 3.4 \\
\text { - Health level } 3.0 \text { vs } 3.6 \\
\text { - Daily life ability } 3.4 \text { vs } 3.7 \\
\text { - Satisfied with yourself } 3.5 \text { vs } 3.7 \\
\text { - Interpersonal relationships } 3.8 \text { vs } 3.9 \\
\text { - Habitation condition } 3.3 \text { vs } 3.5 \\
\text { - Daily life energy } 3.0 \text { vs } 3.4 \\
\text { - Payment ability } 2.6 \text { vs } 2.8\end{array}$ \\
\hline Wang, 2016 [27] & $\begin{array}{l}\text { China / } \\
\text { Mainland }\end{array}$ & $\begin{array}{l}\text { Population-based } \\
2013\end{array}$ & $\begin{array}{l}\text { ID Migraine } \\
\text { Screener - } \\
\text { Chinese } \\
\text { version }\end{array}$ & $\begin{array}{l}102 \\
\text { Mean } 51.5 \text { y } \\
84.3 F\end{array}$ & $\begin{array}{l}\text { HRQoL (SF-36) was significantly worse for respondents with } \\
\text { migraine than those without. Domains significantly different } \\
\text { (linear regression, } P<0.05 \text { ) were: } \\
\text { - Role physical }-25.8 \text { mean difference } \\
\text { - Role emotional }-17.1 \\
\text { - General health }-13.0 \\
\text { - Bodily pain }-10.9 \\
\text { - Physical functioning - } 3.8\end{array}$ \\
\hline Hung, 2006 [34] & $\begin{array}{l}\text { China / } \\
\text { Taiwan }\end{array}$ & $\begin{array}{l}\text { Cross-sectional- } \\
\text { other: headache } \\
\text { clinic } \\
\text { 2003-2004 }\end{array}$ & ICHD-II & $\begin{array}{l}281 \text { adults } \\
\text { Mean } 35.3 \text { y } \\
20-50 y \\
77.6 \mathrm{~F}\end{array}$ & $\begin{array}{l}\text { MIDAS-T } \\
\text { Mean score: } 34.2 \pm 45.9 \text { (severe disability) } \\
\text { - Days missed from work/school } 4.6 \pm 9.9 \\
\text { - Reduced effectiveness days at work/school } 8.2 \pm 12.2 \\
\text { - Days missed from housework } 7.1 \pm 14.0 \\
\text { - Reduced effectiveness in housework } 8.0 \pm 12.1 \\
\text { - Days missed from family, social, or leisure activities } \\
6.5 \pm 13.9\end{array}$ \\
\hline Wang, 2013 [46] & $\begin{array}{l}\text { China / } \\
\text { Taiwan }\end{array}$ & $\begin{array}{l}\text { Cross-sectional } \\
\text { other: headache } \\
\text { clinics } \\
2011\end{array}$ & $\begin{array}{l}\text { Neurologist } \\
\text { diagnosis / } \\
\text { ICHD-II }\end{array}$ & $\begin{array}{l}331 \text { adults } \\
\text { Mean, } 41 \\
77.7 \mathrm{~F}\end{array}$ & $\begin{array}{l}\text { MIDAS scores for chronic migraine vs episodic migraine: } \\
\text { - } 46.1 \pm 49.2 \text { (grade IV-B) vs EM: } 14.4 \pm 23.4 \text { (grade III), } \\
P<0.001 \% \text { MIDAS with severe disability: } 59.3 \% \text { vs } 21.9 \% \\
\text { - \% MIDAS with very severe disability: } 41.3 \% \text { vs } 7.9 \% \\
\text { MSQ for chronic migraine vs episodic migraine: } \\
\text { - Role function restrictive }(56.4 \pm 17.3 \text { vs } 70.8 \pm 13.8, P<0.001 \text { ) } \\
\text { - Role function preventive }(70.0 \pm 18.2 \text { vs } 81.4 \pm 16.2, P<0.001 \text { ) } \\
\text { - Emotional function scores }(62.0 \pm 23.0 \text { vs } 78.1 \pm 16.8, P<0.001 \text { ) } \\
\text { EQ-5D VAS chronic migraine vs episodic migraine: } \\
\text { - } 67.4 \pm 18.7 \text { vs } 82.3 \pm \text { NR, } P<0.001\end{array}$ \\
\hline
\end{tabular}

\begin{tabular}{|c|c|c|c|c|}
\hline Wang, 2001 [42] & $\begin{array}{l}\text { China / } \\
\text { Taiwan }\end{array}$ & $\begin{array}{l}\text { Cross-sectional } \\
\text { other: headache } \\
\text { clinic }\end{array}$ & $\mathrm{H}$ & $\begin{array}{l}193 \text { adults } \\
\text { Mean } 41.8 \text { y } \\
80 \mathrm{~F}\end{array}$ \\
\hline
\end{tabular}

Sakai, 1997 [51] Japan

ligaya, 2003 [49] Japan

Roh, 1998 [59] South Korea other: headache clinics 2000 migraine)

272 adults

$\geq 15$ y
Compared with SF-36 normative data (0-100) for Taiwanese women, migraine had the greatest effect on bodily pain and role emotional:

- Role physical 77.6 vs 56.0

- Bodily pain 79.4 vs 49.7

- General health 63.3 vs 49.5

- Vitality 65.3 vs 50.9

- Social functioning 85.3 vs 67.9

- Role emotional 79.9 vs 54.2

- Mental health 71.8 vs 61.6

$74.2 \%$ had significant impairment in daily living (not defined): - Disability in social activity: severe (4.5\%), moderate (27.5\%), mild/none (68.0\%)

- Daily activity impairment: required bedrest always (4\%), frequently required bedrest with severely impaired daily activity (30\%), moderate impairment of daily activity (40\%), minor impairment (21\%), no impairment (5\%)

Cross-sectional IHS 99 patients with

migraine and or $T$ TH

$46.5 \%$ of patients were MIDAS grade I or II (minimal, mild, or infrequent disability), 22.2\% were MIDAS grade III (moderate disability), and $31.3 \%$ were MIDAS grade IV (severe disability) Mean 42.7 y $80.8 \mathrm{~F}$

$24.3 \mathrm{~F}$
$19.1 \%$ discontinued daily activities because of migraine $34.4 \%$ canceled work or social activities because of migraine 
Table 1 Studies reporting humanistic burden of migraine (Continued)

\begin{tabular}{|c|c|c|c|c|c|}
\hline Citation & $\begin{array}{l}\text { Country/ } \\
\text { region }\end{array}$ & $\begin{array}{l}\text { Study design } \\
\text { Study dates } \\
\text { Migraine criteria }\end{array}$ & $\begin{array}{l}\text { Migraine } \\
\text { criteria }\end{array}$ & $\begin{array}{l}\text { Migraine }(n) \\
\text { Age, } y \\
\% \mathrm{~F}\end{array}$ & Main findings for participants with migraine \\
\hline $\begin{array}{l}\text { Kim, 2012; Kim, } \\
\text { 2013; Chu, } 2013 \\
\text { [55-57] }\end{array}$ & $\begin{array}{l}\text { South } \\
\text { Korea }\end{array}$ & $\begin{array}{l}\text { Population-based } \\
2009\end{array}$ & ICHD-II & $\begin{array}{l}92 \text { adults } \\
\geq 19 \text { y NR }\end{array}$ & $\begin{array}{l}\text { Mean HIT-6 scores: } 51.9 \text { for women and } 51.8 \text { for men } \\
\text { - Little or no impact, } 42.8 \%-42.9 \% \\
\text { - Some impact, } 25.3 \%-25.7 \% \\
\text { - Substantial impact, } 13.0 \%-13.2 \% \\
\text { - Severe impact, } 18.5 \%-18.7 \% \\
\text { Over the past } 3 \text { mo, patients with migraine experienced: } \\
\text { - Restriction in activities for a mean of } 2.7 \text { days } \\
\text { - Missing activities for a mean of } 2.8 \text { days }\end{array}$ \\
\hline
\end{tabular}

Adolescents/children

$\begin{array}{llll}\text { Lu, 2000 [36] } & \begin{array}{l}\text { China / } \\ \text { Taiwan }\end{array} & \begin{array}{l}\text { Population-based IHS } \\ \text { 1998-1999 }\end{array} & \text { 277 adolescents } \\ & & & 13-15 \mathrm{y} \\ & & 58.8 \mathrm{~F} \\ \text { Goto, 2017 [48] Japan } & \begin{array}{l}\text { Population-based IHS } \\ \text { 2012 }\end{array} & 131 \text { adolescents } \\ & & 6-12 \mathrm{y}: 42.5 \mathrm{~F} \\ & & 12-15 \mathrm{y}: 67.2 \mathrm{~F}\end{array}$

$30.4 \%$ of children with migraine were absent from school because of headache in the previous semester: $1-3$ days $27 \%$, $\geq 4$ days $3.4 \%$

Feeling fed up or irritated, having difficulty concentrating were significantly more common ( $P=0.010$ and $P=0.017$, respectively) in migraine than $\mathrm{TTH}$

For children with migraine, the number of days for the past 3 mo that disability affected school life, including school absences, arriving late, leaving early, or having difficulty participating in physical activities, ranged from 1.7 (SD 1.2) days to 3.8 (SD 3.7) days

EQ-5D European Quality of Life 5-Dimensions questionnaire; F female; HIT-6 Headache Impact Test; HRQoL health-related quality of life; ICHD-I/IIIII 3 International Classification of Headache Disorders; IHS International Headache Society; MSQ Migraine-Specific Quality-of-Life Questionnaire; MIDAS Migraine Disability Assessment Questionnaire; NR not reported; SD standard deviation; SF-36 Short-Form 36-item survey; TTH tension-type headache; VAS visual analog scale

(USD 140 million) per year due to lost work days. Women of all ages accounted for approximately $80 \%$ of costs, with women aged 35 to 54 years accounting for approximately $56 \%$ of costs [33].

The remaining studies, which were conducted between 1999 and 2018, reported observational outcomes related to missed work days and productivity from Japan $[52,53]$ and South Korea [54]. Overall, between 20\% and 28\% of individuals missed work or could not do housework because of headache, and more individuals with headache took greater sick leave and had lower productivity compared with individuals without headache (Table 2).

\section{Clinical management of migraine in adults}

A total of 12 studies (14 publications) reporting information on clinical management of migraine in adults were retrieved (Table 3); 6 studies were population-based and 6 were other cross-sectional studies of headache patients or neurologists. Findings from the population-based studies reflected similar findings from the cross-sectional studies and, collectively, these studies showed a high degree of underdiagnosis and/or undertreatment (Table 3).

\section{China}

Of the individuals or patients with migraine from China, $52.9 \%$ to $68.6 \%$ had consulted a physician previously, $37.2 \%$ to $52.7 \%$ who were diagnosed with headache had not been diagnosed with migraine previously, and $13.5 \%$ to $18 \%$ had been diagnosed with migraine previously (Table 3). In Taiwan, most patients with migraine from the general population consulted general practitioners (29\% to $41 \%)$ and neurologists $(12 \%$ to $28 \%)$ [35, 44]. For patients with refractory migraine at neurology clinics, most patients with chronic or episodic migraine $(79.0 \%$ and $80.6 \%$ ) had consulted a neurologist or specialist in the previous 3 months for their migraine, and $34.3 \%$ and 24.6\% had consulted a general practitioner [46].

With regard to treatment, findings from a crosssectional study of 401 migraine outpatients from a neurological clinic in mainland China showed that within the previous 3 months of being surveyed, $43.1 \%$ of individuals had not used analgesics, $2.7 \%$ had used preventives, and none had used triptans $[22,28]$. In contrast, findings from an analysis conducted at a similar time of 311 migraine outpatients from Taiwan showed that $31.7 \%$ and $48.5 \%$ of patients with episodic and chronic migraine, respectively, had taken preventives [46].

One nationwide survey assessed the attitudes and migraine practice patterns of neurologists in Taiwan [37]. Of the 123 respondents to the survey, 88.5\% indicated that headache was an important part of their practice, $40.2 \%$ found headache patients to be time-consuming, and $89.9 \%$ considered behavioral therapy to be an important part of treatment. With regard to practice patterns, $69.9 \%$ of the responding neurologists agreed that preventive medication was indicated for patients with $\geq 2$ migraine attacks per week. In addition, approximately one-third $(32.5 \%)$ had never prescribed triptans, mostly because of cost (35\%) at the time this study was conducted. Almost all neurologists (97.4\%) had encountered 
Table 2 Studies reporting economic burden of migraine

\begin{tabular}{|c|c|c|c|c|c|}
\hline Citation & $\begin{array}{l}\text { Country/ } \\
\text { region }\end{array}$ & $\begin{array}{l}\text { Study design } \\
\text { Study dates }\end{array}$ & Migraine criteria & $\begin{array}{l}\text { Migraine }(n) \\
\text { Age, y } \\
\% \mathrm{~F}\end{array}$ & Main findings \\
\hline $\begin{array}{l}\mathrm{Yu}, 2012 \\
{[29]}\end{array}$ & $\begin{array}{l}\text { China / } \\
\text { Mainland }\end{array}$ & $\begin{array}{l}\text { Population-based } \\
2009\end{array}$ & ICHD-II & $\begin{array}{l}469 \text { respondents } \\
\text { Mean } 46.2 \text { y } \\
67.6 \mathrm{~F}\end{array}$ & $\begin{array}{l}\text { Over the past } 3 \text { mo, average (SD): } \\
\text { - Days of missed work } 2.7(7.5) \\
\text { - Impaired work days } 4.0(8.1) \\
\text { - Missed housework days } 3.3(7.1) \\
\text { - Impaired housework days } 4.7 \text { ( } 8.6) \\
\text { Indirect costs due to migraine-related lost productivity: } \\
\text { CNY } 273.7 \text { billion (USD } 39.4 \text { billion) } \\
\text { Direct costs (diagnosis / treatment out-of-pocket expenses) } \\
\text { per person affected year: CNY } 729 \\
\text { Direct costs per year CNY } 58.0 \text { billion (USD } 8.4 \text { billion) } \\
\text { Total annual cost of migraine per year: CNY } 331.7 \text { billion } \\
\text { (USD } 47.8 \text { billion) }\end{array}$ \\
\hline $\begin{array}{l}\text { Fuh, } 2008 \\
\text { [33] }\end{array}$ & $\begin{array}{l}\text { China / } \\
\text { Taiwan }\end{array}$ & $\begin{array}{l}\text { Population-based } \\
\text { 1997-1998 }\end{array}$ & $\begin{array}{l}\text { IHS migraine and } \\
\text { modified migraine } \\
\text { (IHS and attacks } \\
\text { 2- to 4-h duration) }\end{array}$ & $\begin{array}{l}1813 \text { employees } \\
\text { NR } \\
43.2 \mathrm{~F} \\
1809 \text { non- } \\
\text { employees } \\
\text { NR } \\
\text { NR }\end{array}$ & $\begin{array}{l}\text { Over the past } 1 \mathrm{y} \text { : } \\
\text { - Median no. of missed days/employee, } 2 \text { days } \\
\text { - Estimated median cost due to missed workdays/person } \\
\text { in subjects with migraine vs without migraine: } \\
\text { NTD } 1667 \text { vs NTD } 0, P<0.001 \\
\text { Projected annual number of missed workdays and } \\
\text { economic loss attributed to migraine in 2005: } \\
\text { - } 3.7 \text { million missed workdays/y (3.06 million in women, } \\
0.64 \text { million in men) } \\
\text { - Estimated annual cost of migraine was NTD } 4873 / \text { person } \\
\text { - Estimated cost of NTD } 4.6 \text { billion/y due to lost workdays } \\
\text { - Women accounted for } \sim 80 \% \text { of total cost }(\sim 56 \% \text { of total } \\
\text { cost attributed to women aged } 35-54 \text { y) }\end{array}$ \\
\hline
\end{tabular}

Tang, 2013 China / Cross-sectional

[38] Taiwan other: retrospective casecontrol analysis of NHIRD 1996-2009
Takeshima, Japan 2004 [53]
Refractory migraine (ICD-9-CM)
936 patients with refractory migraine vs 3743 nonmigraine controls Mean 42 y $76 \mathrm{~F}$ 673 patients with refractory migraine vs 2202 with other migraine Mean age 41-42 y 79-80 F

All analyses adjusted for age, gender, urbanization level, income, and comorbidities

Refractory migraine vs non-migraine adjusted for sociodemographic factors/comorbidity, mean (SD)

Frequency of care:

- Outpatient visits: 35.5 (33.2) vs 16.5 (14.4), $P<0.0001$

- Emergency visits: $1.2(1.3)$ vs $0.3(0.3), P<0.0001$

- Hospital admission: 0.7 (0.8) vs $0.3(0.3), P<0.0001$

- Hospital days: 7.1 (11.5) vs 2.4 (4.7), $P<0.0001$

Annual total drug costs per person: NTD 19,752

(USD 608) vs NTD 8660 (USD 266), $P<0.0001$

Annual total medical costs per person: NTD 57,932 (USD 1783) vs NTD 26,817 (USD 825), $P<0.0001$

Refractory migraine vs other migraine adjusted for sociodemographic factors/comorbidity, mean (SD)

Frequency of care:

- Outpatient visits: 36.3 (23.0) vs 26.2 (12.3), $P<0.0001$

- Emergency visits: 1.4 (1.6) vs $0.5(0.5), P<0.0001$

- Hospital admission: $0.6(0.8)$ vs $0.3(0.3), P<0.0001$

- Hospital days 7.0 (10.9) vs 2.7 (5.1), $P<0.0001$

Annual total drug costs per person: NTD 17,623 (USD 542) vs NTD 10,088 (USD 310), $P<0.0001$

Annual total medical costs per person: NTD 54,678 (USD 1682) vs NTD 38,397 (USD 1181), $P<0.0001$

342 adults $\geq 20$ y $81.6 \mathrm{~F}$

Over the past 3 mo:

- $20.3 \%$ had time off work due to headache

- $25.8 \%$ with MWA had time off work (mean no. of days: 1.8)

- $19.5 \%$ with MOA had time off work (mean no. of days: 3.8)

- $27.3 \%$ with MWA were unable to do housework (mean no. of days: 2.0)

- $28.0 \%$ with MOA were unable to do housework (mean no. of days: 2.8)

\begin{tabular}{|c|c|c|c|c|}
\hline $\begin{array}{l}\text { Suzuki, } \\
2014 \text { [52] }\end{array}$ & Japan & $\begin{array}{l}\text { Community-based } \\
\text { 2007-2008 }\end{array}$ & |CHD-II & $\begin{array}{l}704 \text { Tokyo } \\
\text { employees } \\
\geq 20 \text { y } 77.4 \mathrm{~F}\end{array}$ \\
\hline $\begin{array}{l}\text { Choi, } 2018 \\
{[54]}\end{array}$ & $\begin{array}{l}\text { South } \\
\text { Korea }\end{array}$ & $\begin{array}{l}\text { Cross-sectional } \\
\text { other: prospective } \\
\text { disease registry }\end{array}$ & $\mid C H D-\| \beta$ & $\begin{array}{l}38^{\mathrm{a}} \text { adults } \\
\text { Mean, } 37.6 \\
15.7 \mathrm{~F}\end{array}$ \\
\hline
\end{tabular}

$25.1 \%$ had to miss work because of headache $2.7 \%$ could not work once per mo

Employed patients with migraine compared with employed control patients without headache: - Experienced difficulty at work (63.9\% vs 36.5\%) 
Table 2 Studies reporting economic burden of migraine (Continued)

\begin{tabular}{|c|c|c|c|c|c|}
\hline Citation & $\begin{array}{l}\text { Country/ } \\
\text { region }\end{array}$ & $\begin{array}{l}\text { Study design } \\
\text { Study dates }\end{array}$ & Migraine criteria & $\begin{array}{l}\text { Migraine (n) } \\
\text { Age, y } \\
\% \mathrm{~F}\end{array}$ & Main findings \\
\hline & & 2016-2018 & & & $\begin{array}{l}\text { - Had low productivity (33.3\% vs } 11.5 \%) \\
\text { - Greater sick leave ( } 13.9 \% \text { vs } 3.8 \%) \\
\text { Migraine or TTH was significantly associated with difficulties } \\
\text { at work after adjustment for health, anxiety, and stress } \\
\text { (OR 3.05; } 95 \% \mathrm{Cl}, 1.10-8.49 ; P=0.032 \text { ) }\end{array}$ \\
\hline
\end{tabular}

${ }^{a}$ This study enrolled 143 patients with cluster headache, 38 age- and sex-matched patients with migraine or $\mathrm{TH}$, which included 5 patients had chronic migraine, 25 with episodic migraine, and 8 with TH (4 chronic and 4 episodic), and 52 individuals without headache. Patients with cluster headache are not reported here Cl confidence interval; $C N Y$ Chinese yen; F female; ICHD-I/IIIIII International Classification of Headache Disorders; IHS International Headache Society; MOA migraine without aura; MWA migraine with aura; NHIRD Taiwan National National Health Insurance Database; NR not reported; NTD New Taiwanese dollar; OR odds ratio; SD standard deviation; $T H H$ tension-type headache; USD United States dollar

patients with headache who chronically used liquid forms of over-the-counter (OTC) medication with a combination of caffeine, acetaminophen, and other components.

\footnotetext{
Japan

Of individuals or patients with migraine from Japan [50-53], 59.4\% to $71.8 \%$ had never consulted a physician previously, $1.3 \%$ to $7.3 \%$ regularly consulted a physician for their headache, and only $11.6 \%$ of individuals with migraine were aware that they had migraine. The main reasons for not consulting (or not consulting continuously) a physician for headache were that the headache was not severe enough or respondents could endure their symptoms, the headache improved spontaneously, OTC medication was effective, or the patient could not miss work [50, 53]. The most common reasons for no longer consulting a physician were being told their condition was not fatal, unable to get adequate advice, and no time [52].

With regard to treatment, $19.2 \%$ of patients from a population-based study were not taking any medication, $56.8 \%$ were taking OTC medication, $18.6 \%$ were taking OTC and prescription medication, and $5.4 \%$ were taking prescription medication only [51].
}

\section{South Korea}

There was limited information on health care utilization or clinical/treatment patterns from South Korea. Findings from one population-based study showed that only $24.4 \%$ of individuals with migraine had consulted a physician for headache, $64.3 \%$ were taking medication for their headache and, of these, most $(92.8 \%)$ were using OTC medication [59].

\section{Burden and clinical management of migraine in children} For children, 2 population-based studies reporting information on burden or clinical management were retrieved: 1 from Taiwan [36] and 1 from Japan [48]. In both studies, migraine was associated with absenteeism from school, and difficulties in concentrating and in participating in physical activities $[36,48]$.

Findings from the study in Japan [48] showed that the numbers of school days over 3 months that were disrupted because of migraine among elementary and junior high school students, respectively, were 3.8 and 1.7 days for leaving early or arriving late, 2.7 and 2.6 days for absences, and 3.3 and 3.6 days for difficulty performing activities. Students reported feeling fed up, irritated, and had difficulty concentrating. Of the children who reported migraine-related disability, many $(47.9 \%$ of $6-$ to 12 -year-olds and $44.9 \%$ of 12 - to 15 -year-olds) had not consulted a physician for their migraine. In addition, $8.3 \%$ of junior high school students and $30.6 \%$ of elementary school students were not taking medication or only took OTC medication for their migraine.

In Taiwan [36], over the semester assessed, up to $30.4 \%$ of children with migraine had been absent from school because of headache; $27.0 \%$ were absent for 1 to 3 days, and $3.4 \%$ were absent for 4 or more days. Absence from school because of headache was significantly higher among students with migraine compared with those without migraine $(30.4 \%$ vs $14.0 \%, P<0.0001)$. A large proportion (72.1\%) of children (13- to 15-yearolds) took painkillers for their migraine, with $11.5 \%$ taking painkillers more than once per week.

\section{Discussion}

The findings from this comprehensive review of the literature suggest that there are unmet needs for migraine in terms of sufficient and appropriate diagnosis, and better management and therapies for treatment of migraine in East Asia. However, despite the number of publications retrieved from the literature review, there were significant gaps in the literature. The focus of most studies was the prevalence of migraine, with very little information on migraine burden or clinical management of migraine, particularly in South Korea or in children and adolescents. Although there were a considerable number of population-based studies, many were conducted before 2004, before the release of the ICHD-II criteria, and 
Table 3 Studies reporting clinical management of migraine

\begin{tabular}{|c|c|c|c|c|c|}
\hline Citation & $\begin{array}{l}\text { Country/ } \\
\text { region }\end{array}$ & $\begin{array}{l}\text { Study design } \\
\text { Study dates }\end{array}$ & Migraine criteria & Population (n) & Main findings for participants with migraine \\
\hline $\begin{array}{l}\text { Wang, } \\
2011 \text { and } \\
\text { Li, } 2012 \\
{[22,28]}\end{array}$ & $\begin{array}{l}\text { China / } \\
\text { Mainland }\end{array}$ & $\begin{array}{l}\text { Cross-sectional } \\
\text { other: } \\
\text { neurological } \\
\text { outpatient } \\
\text { department } \\
2010\end{array}$ & ICHD-II & $\begin{array}{l}401 \text { patients with } \\
\text { migraine }\end{array}$ & $\begin{array}{l}\text { Practice pattern over the past } 1 \mathrm{y} \text { : } \\
\text { - } 68.6 \% \text { of patients had consulted a physician, } \\
13.5 \% \text { were diagnosed with migraine, } \\
37.2 \% \text { had not received any diagnosis } \\
\text { Treatment over the past } 3 \text { mo: } \\
\text { - } 43.1 \% \text { had not used analgesics for migraine, } 11.7 \% \text { were } \\
\text { using analgesics } \geq 3 \text { days/wk., none had used triptans, } \\
2.7 \% \text { had used preventive drugs }\end{array}$ \\
\hline $\begin{array}{l}\text { Liu, } 2013 \\
{[24]}\end{array}$ & $\begin{array}{l}\text { China / } \\
\text { Mainland }\end{array}$ & $\begin{array}{l}\text { Population-based } \\
2009\end{array}$ & ICHD-\|I & $\begin{array}{l}452 \text { adults with } \\
\text { migraine }\end{array}$ & $\begin{array}{l}\text { Practice pattern over the past } 1 \text { y: } \\
\text { - } 52.9 \% \text { of adults had consulted a physician for headache } \\
\text { - } 52.7 \% \text { of adults who had a consultation for headache } \\
\text { were undiagnosed } \\
\text { - } 13.8 \% \text { were diagnosed with migraine, the remaining } \\
\text { were diagnosed with other headache disorders } \\
\text { Significant predictors of consultation for migraine } \\
\text { were mild, moderate, or severe disability (HALT index) vs } \\
\text { minimal HALT ( } 0-5 \text { days lost/3 mo): } \\
\text { - Mild } 6-10 \text { days lost: adjusted OR } 3.4(95 \% \mathrm{Cl}, 1.6-7.4) \\
\text { - Moderate } 11-20 \text { days lost: adjusted OR } 2.5 \text { (95\% Cl, 1.2-5.4) } \\
\text { - Severe > } 20 \text { days lost: adjusted OR } 3.9 \text { ( } 95 \% \mathrm{Cl}, 1.9-8.1)\end{array}$ \\
\hline $\begin{array}{l}\text { Lu, } 2001 \\
{[35]}\end{array}$ & $\begin{array}{l}\text { China / } \\
\text { Taiwan }\end{array}$ & $\begin{array}{l}\text { Population-based } \\
\text { 1997-1998 }\end{array}$ & $\begin{array}{l}>15 \text { headache days/ } \\
\text { mo for }>1 \mathrm{mo} ;>4-\mathrm{h} \\
\text { duration }\end{array}$ & $\begin{array}{l}108 \text { adults with } \\
\text { chronic daily headache }\end{array}$ & $\begin{array}{l}\text { Practice pattern and treatment over the past } 1 \mathrm{y} \text { : } \\
\text { - } 57 \% \text { had consulted a physician for their headache } \\
\text { - } 41 \% \text { consulted their family physician, } 28 \% \text { neurologist } \\
\text { - } 5 \% \text { were treated with preventive drugs }\end{array}$ \\
\hline $\begin{array}{l}\text { Wang, } \\
\text { 2000; } \\
\text { Wang, } \\
2001[43, \\
44]\end{array}$ & $\begin{array}{l}\text { China / } \\
\text { Taiwan }\end{array}$ & $\begin{array}{l}\text { Population-based } \\
\text { 1997-1998 }\end{array}$ & $\begin{array}{l}\text { IHS migraine and } \\
\text { modified migraine } \\
\text { (IHS + attacks of 2- to } \\
\text { 4-h duration) }\end{array}$ & $\begin{array}{l}328 \text { adults with } \\
\text { migraine }\end{array}$ & $\begin{array}{l}\text { Practice pattern over the past } 1 \mathrm{y} \text { : } \\
\text { - } 54 \% \text { had consulted a physician for the headache } \\
\cdot 18 \% \text { of these had been diagnosed with migraine by their } \\
\text { physician } \\
\text { Treating physicians } \\
\cdot 29 \% \text { general practitioners } \\
\cdot 17 \% \text { internists, } 14 \% \text { ENT specialists, } 12 \% \text { neurologists } \\
\text { - } 4.9 \% \text { gynecologists, } 4.6 \% \text { ophthalmologists, } 1.2 \% \text { allergists, } \\
2.7 \% \text { other }\end{array}$ \\
\hline $\begin{array}{l}\text { Lu, } 2006 \\
{[37]}\end{array}$ & $\begin{array}{l}\text { China / } \\
\text { Taiwan }\end{array}$ & $\begin{array}{l}\text { Cross-sectional } \\
\text { other: } \\
\text { neurologists in } \\
\text { Taiwan } \\
\text { NR }\end{array}$ & NA & $\begin{array}{l}123 \text { neurologists in } \\
\text { Taiwan }\end{array}$ & $\begin{array}{l}31.7 \% \text { of patients seen were outpatients with migraine } \\
\text { Attitudes: } \\
\text { - } 88.5 \% \text { reported headache to be an important part of their } \\
\text { practice } \\
\text { - } 40.2 \% \text { thought headache patients to be time-consuming } \\
\text { - } 86.9 \% \text { reported patient satisfaction as an important } \\
\text { consideration for treatment } \\
\text { - } 89.9 \% \text { thought behavioral therapy to be an important part } \\
\text { of treatment } \\
\text { Treatment: } \\
\text { - } 69.9 \% \text { agreed that preventive medication was indicated } \\
\text { for } \geq 2 \text { migraine attacks/wk., but } 12.2 \% \text { prescribed } \\
\text { preventives for patients with } \geq 14 \text { headaches/mo } \\
\text { - Most commonly prescribed drugs were beta-blockers } \\
\text { (96.7\%), flunarizine }(87.0 \%) \text {, tricyclic antidepressants } \\
\text { (80.5\%), and valproic acid (54.5\%) } \\
\text { - } 32.5 \% \text { had never prescribed triptans, mostly because of } \\
\text { cost (35\%) }\end{array}$ \\
\hline $\begin{array}{l}\text { Wang, } \\
2008 \text { [39] }\end{array}$ & $\begin{array}{l}\text { China / } \\
\text { Taiwan }\end{array}$ & $\begin{array}{l}\text { Cross-sectional } \\
\text { other: } \\
\text { neurological } \\
\text { clinics } \\
2005\end{array}$ & $\begin{array}{l}\text { ICHD-II (MOA, MWA, } \\
\text { probable) }\end{array}$ & $\begin{array}{l}755 \text { patients with } \\
\text { headache attending a } \\
\text { neurology clinic for the } \\
\text { first time }\end{array}$ & $\begin{array}{l}60 \% \text { were diagnosed by neurologists with migraine } \\
48 \% \text { had MWA or MOA (ICHD-II) } \\
71 \% \text { had any migraine type (ICHD-II) of these, } 23 \% \text { were not } \\
\text { diagnosed by neurologists as having migraine } \\
57.4 \% \text { diagnosed with any migraine (ICHD-II) had never } \\
\text { been diagnosed with migraine previously }\end{array}$ \\
\hline $\begin{array}{l}\text { Wang, } \\
2013 \text { [46] }\end{array}$ & $\begin{array}{l}\text { China / } \\
\text { Taiwan }\end{array}$ & $\begin{array}{l}\text { Cross-sectional } \\
\text { other: headache } \\
\text { clinics } \\
2011\end{array}$ & $\begin{array}{l}\text { Neurologist diagnosis } \\
\text { / ICHD-II }\end{array}$ & $\begin{array}{l}331 \text { adults with } \\
\text { migraine at neurology } \\
\text { clinics }\end{array}$ & $\begin{array}{l}\text { Over the past } 3 \text { mo for chronic migraine vs episodic } \\
\text { migraine } \\
\text { Health care professional evaluation of headache: } 85.6 \% \text { vs } \\
81.7 \% \\
\text { - General practitioner: } 34.3 \% \text { vs } 24.6 \% \\
\text { - Neurologist/specialist: } 79.0 \% \text { vs } 80.6 \% \\
\text { - Emergency room visits: } 21.0 \% \text { vs } 5.5 \% \\
\text { - Hospital admission: } 4.8 \% \text { vs } 0 \% \\
\text { - Preventive medication: } 48.5 \% \text { vs } 31.7 \%\end{array}$ \\
\hline
\end{tabular}


Table 3 Studies reporting clinical management of migraine (Continued)

\begin{tabular}{|c|c|c|c|c|c|}
\hline Citation & $\begin{array}{l}\text { Country/ } \\
\text { region }\end{array}$ & $\begin{array}{l}\text { Study design } \\
\text { Study dates }\end{array}$ & Migraine criteria & Population (n) & Main findings for participants with migraine \\
\hline $\begin{array}{l}\text { Sakai, } 1997 \\
{[51]}\end{array}$ & Japan & $\begin{array}{l}\text { Population-based } \\
\text { NR }\end{array}$ & $\begin{array}{l}\text { IHS migraine and } \\
\text { modified migraine } \\
\text { (IHS + attacks of 2- to } \\
\text { 4-h duration) }\end{array}$ & $\begin{array}{l}338 \text { adults with IHS- } \\
\text { defined or other de- } \\
\text { fined migraine }\end{array}$ & $\begin{array}{l}\text { 69.4\% had never consulted a physician for headache } \\
11.6 \% \text { were aware their headache was migraine } \\
56.8 \% \text { were taking OTC drugs } \\
5.4 \% \text { were taking prescription drugs } \\
\text { 18.6\% were taking OTC and prescription drugs } \\
\text { 19.2\% were not taking any medication }\end{array}$ \\
\hline $\begin{array}{l}\text { Takeshima, } \\
2004[53]\end{array}$ & Japan & $\begin{array}{l}\text { Population-based } \\
1999\end{array}$ & $\mathrm{IHS}$ & $\begin{array}{l}\text { Adults } \\
41 \text { with MWA } 301 \text { with } \\
\text { MOA }\end{array}$ & $\begin{array}{l}\text { MWA vs MOA } \\
\text { Most never consulted a physician for migraine } \\
61.0 \% \text { vs } 71.8 \% \\
\text { Few continuously consulted a physician } \\
\text { for migraine } 7.3 \% \text { vs } 5.3 \% \\
\text { Main reasons for not consulting or not } \\
\text { continuing to consult a physician: } \\
\text { • Headache not severe enough } \\
35.7 \% \text { vs } 29.3 \% ; 38.5 \% \text { vs } 30.4 \% \\
\text { - Will improve spontaneously after standing } \\
57.1 \% \text { vs } 56.9 \% ; 30.8 \% \text { vs } 27.5 \% \\
\text { - OTC medication effective } \\
21.4 \% \text { vs } 53.7 \% ; 23.1 \% \text { vs } 30.4 \%\end{array}$ \\
\hline $\begin{array}{l}\text { Kotani, } \\
2004[50]\end{array}$ & Japan & $\begin{array}{l}\text { Cross-sectional: } \\
\text { other } \\
\text { NR }\end{array}$ & $\mathrm{HS}$ & $\begin{array}{l}35 \text { patients with } \\
\text { migraine at a general } \\
\text { health clinic }\end{array}$ & $\begin{array}{l}\text { Main reasons for not previously seeking medical attention: } \\
\cdot 28.6 \% \text { can endure symptoms without medication } \\
\cdot 28.6 \% \text { OTC medication is effective } \\
\cdot 28.6 \% \text { could not miss work } \\
\cdot 25.7 \% \text { could sleep and wake pain-free }\end{array}$ \\
\hline $\begin{array}{l}\text { Suzuki, } \\
2014[52]\end{array}$ & Japan & $\begin{array}{l}\text { Community- } \\
\text { based } \\
\text { 2007-2008 }\end{array}$ & ICHD-II & $\begin{array}{l}704 \text { employees in } \\
\text { Tokyo }\end{array}$ & $\begin{array}{l}1.3 \% \text { regularly visited their physicians } \\
59.4 \% \text { had never consulted with a physician about their } \\
\text { headaches } \\
\text { The most common reasons ( } n=173) \text { for stopping visits to a } \\
\text { physician were: told their condition was not fatal }(45.1 \%) \text {, } \\
\text { unable to get adequate advice from their physician }(20.2 \%) \text {, } \\
\text { and no time }(14.5 \%)\end{array}$ \\
\hline $\begin{array}{l}\text { Roh, } 1998 \\
{[59]}\end{array}$ & $\begin{array}{l}\text { South } \\
\text { Korea }\end{array}$ & $\begin{array}{l}\text { Population-based } \\
1996\end{array}$ & $\mathrm{IHS}$ & $\begin{array}{l}272 \text { adults with } \\
\text { migraine }\end{array}$ & $\begin{array}{l}\text { 64.3\% used medication for their migraine } \\
92.8 \% \text { used OTC medication } \\
24.4 \% \text { had consulted a physician for headache }\end{array}$ \\
\hline \multicolumn{6}{|c|}{ Children/adolescents } \\
\hline $\begin{array}{l}\text { Lu, } 2000 \\
{[36]}\end{array}$ & $\begin{array}{l}\text { China/ } \\
\text { Taiwan }\end{array}$ & $\begin{array}{l}\text { Population-based } \\
\text { 1998-1999 }\end{array}$ & IHS & $\begin{array}{l}\text { Children } \\
13-15 \text { y, } 277\end{array}$ & $\begin{array}{l}\text { 72.1\% of children used painkillers for their headache } \\
11.5 \% \text { used painkillers } \geq 1 \mathrm{~d} / \mathrm{wk}\end{array}$ \\
\hline $\begin{array}{l}\text { Goto, } 2017 \\
{[48]}\end{array}$ & Japan & $\begin{array}{l}\text { Population-based } \\
2012\end{array}$ & $\begin{array}{l}\text { ICHD-III } \beta \text { (unilateral } \\
\text { aura not included) }\end{array}$ & $\begin{array}{l}\text { Children } \\
6-12 y, 48 \\
12-15 y, 37\end{array}$ & $\begin{array}{l}\text { Elementary school and junior high school students who } \\
\text { reported disability due to migraine: } \\
\text { - } 44.9 \% \text { and } 47.9 \% \text { had not had a medical consultation for } \\
\text { their migraine } \\
\text { - } 30.6 \% \text { and } 8.3 \% \text { had not received prescription medication } \\
\text { for their migraine }\end{array}$ \\
\hline
\end{tabular}

Cl confidence interval; $F$ female; HALT Headache-Attributed Lost Time Index; ICHD-I/II/III $\beta$ International Classification of Headache Disorders; ICD-9-CM International Classification of Diseases, 9th revision, Clinical Modification; IHS International Headache Society; NA not applicable; NR not reported; MOA migraine without aura; MWA migraine with aura; OTC over-the-counter; OR odds ratio; SD standard deviation

most were conducted more than 5 years ago. Only 3 studies reported on indirect productivity costs associated with migraine disability or direct costs associated with health care utilization or medical costs $[29,33,38]$. Each of these studies were from China and reported on information collected at least 10 years ago.

In 2016, the worldwide, age-standardized prevalence of migraine was estimated to be $14.4 \%$ : $18.9 \%$ for women and $9.8 \%$ for men [6]. Findings from the populationbased studies retrieved in our literature review showed that migraine prevalence among adults in East Asia ranged from $6.0 \%$ to $14.3 \%$ in non-elderly adults, which is consistent with worldwide estimates of migraine prevalence [6] and a previous study conducted among Asia-Pacific countries up until 2013 [16]. Consistent with worldwide studies on migraine disability [6], the peak prevalence of migraine in East Asia was among adult women aged 30 to 49 years. In addition, findings from the current study showed that the prevalence of migraine in children increased with age to approximately $8.5 \%$ at 15 years. An analysis of 64 population-based studies worldwide suggests that the prevalence of migraine in children is $9.1 \%$ [14], which is higher than reported for children in this study. However, this analysis did not account for the many different age groups of the populations assessed or the different criteria used to 
identify migraine across studies. Given that the populations of China, Japan, and South Korea collectively represent $21 \%$ of the global population, these findings highlight the substantial number of people affected by migraine in East Asia.

A major finding from this study is that there appeared to be a low level of disease awareness and use of prescription medication for migraine in East Asia at the time the studies were conducted. Many patients identified as having migraine had not consulted or were not currently seeing a physician for their migraine, and many patients had not been diagnosed with migraine previously, suggesting that migraine is underdiagnosed and, therefore, undertreated. Although the search was limited to publications from 1988 onward, after the availability of triptans for management of acute migraine pain, most patients were not taking medication or were taking OTC medication, and use of both triptans and preventives appeared to be low. These findings are generally consistent with more recent studies, published after this review was conducted, which have shown low prescribing rates for triptans in China [60] and low prescribing rates for preventives in China and Japan [60-62]. However, a recent study on real-world treatment patterns suggests that triptans are now commonly prescribed for patients with migraine in Japan [61].

Although use of complementary medicine and physical treatments such as acupuncture were outside the scope of this review, these therapies have a major role in the management of patients with migraine in East Asia [60, 63, 64]. In East Asia, complementary medicine may comprise traditional herbal preparations or patent medicines (typically prepared as high-quality extracts of herbal treatments). In Japan, traditional patent medicines are prescribed in combination with Western prescription medicine for management of various types of pain including headache and migraine [63] and a recent analysis of the China Health Insurance Association (CHIRA) medical insurance claims database has shown that approximately $25 \%$ of patients are prescribed Chinese patent medicine for migraine [60].

The impact of inadequate treatment on migraine burden and health care utilization was assessed in a global survey of 11,266 individuals with migraine experiencing $\geq 4$ migraine headaches per month, in which $\geq 80 \%$ of respondents had failed preventive treatment at least once [7]. In this survey, $87 \%$ of individuals reported negative effects in their private, social, and professional lives, and high levels of health care utilization. Within a 6-month period, $58 \%$ had had a brain scan, and within a 12 month period, $38 \%$ had visited an emergency department and $23 \%$ had stayed in hospital overnight. In addition, findings from the International Burden of $\mathrm{Mi}$ graine Study [1], which surveyed 8726 individuals from predominantly Caucasian populations with chronic or episodic migraine, showed that approximately 50\% reported moderate or significant levels of disability (MIDAS grade III or IV) and significantly negative effects on HRQoL for those with chronic migraine. Consistent with studies in predominantly Caucasian populations $[1,65]$, the humanistic burden of migraine in East Asia from the available studies has suggested that there are unmet needs for improvements in diagnosis, management, and therapies for treatment of migraine across East Asia. When reported, mean MIDAS scores for headache clinic outpatients in China and Japan indicated severe levels of disability [34, 46, 49]. In addition, HRQoL (SF-36) domains most negatively affected were bodily pain, physical functioning, role physical, and role emotional, which is consistent with findings showing significant impairments in daily activities [27, 46]. For adults, this migraine-related disability translates to significant levels of absenteeism and reduced effectiveness in the workplace and at home, and for children, significant negative effects on school attendance and participation in physical activities.

Although evidence on the economic costs of migraine in this study was limited to 3 studies from China (Table 2 ), the findings demonstrated that migraine was associated with costs of billions of dollars per year arising from lost productivity, drug costs, and direct medical costs. However, in contrast to studies from the United States [66] and Europe [67], the greatest proportion of the costs of migraine in China were attributed to lost productivity [29]. In the United States, direct medical costs were estimated to account for at least $60 \%$ of the total costs of migraine [66], whereas in China, lost productivity was estimated to account for $82 \%$ of total costs [29]. The high costs arising from lost productivity have also been reported in Japan, where lost productivity related to migraine was reported to account for 288 billion yen per year [68].

The strengths of this comprehensive review are that it has provided a detailed overview of the current status of evidence in the peer-reviewed literature on migraine burden and clinical management in East Asia. However, despite the number of studies retrieved, the available evidence was limited, particularly for children. Comparisons across countries and regions need to take into account cultural factors in patient responses to disability, and the socioeconomic status of the populations assessed in each country. However, because of the wide variation in study types, populations, and analysis methods, it was not possible to compare findings between countries.

\section{Conclusion}

In conclusion, despite the high prevalence and significant level of migraine-associated disability reported in 
population-based studies in East Asia, there is little or no information on economic burden associated with migraine or migraine disability, work-related productivity losses, or costs associated with treatment or undertreatment. Combined with the high prevalence of migraine across all countries included in this review, the significant levels of humanistic burden among the available studies suggest that there are substantial unmet needs for migraine with regard to appropriate diagnosis, and better management of and therapies for treatment of migraine across East Asia. However, more recent evidence is required to confirm current unmet needs in each country.

\section{Supplementary information}

Supplementary information accompanies this paper at https://doi.org/10. 1186/s10194-019-1062-4.

Additional file 1. Population-based studies reporting prevalence of migraine

\section{Abbreviations}

CNY: Chinese yuan renminbi; EQ-5D: EuroQoL-5 Dimensions;

HIS: International Headache Society; HRQOL: Health-related quality of life; ICHD: International Classification of Headache Disorders; MIDAS: Migraine Disability Assessment Questionnaire; MSQ: Migraine-Specific QoL Questionnaire; NTD: New Taiwan Dollars; OTC: Over-the-counter; SF-36: 36item Short-Form health survey; USD: United States dollars

\section{Acknowledgements}

Not applicable.

\section{Authors' contributions}

$\Pi \mathrm{Ta}, \mathrm{KU}, \mathrm{MK}, \mathrm{SS}$, and TTr were involved in the study design, SS was involved in the data collection, and all authors were involved in the review and approval of publications to be included in the review. All authors participated in the interpretation of study results, and in the drafting, critical revision, and approval of the final version of the manuscript.

\section{Funding}

This study was sponsored by Eli Lilly and Company. Medical writing assistance was provided by Serina Stretton, PhD, CMPP, and Hiroko Ebina, BPharm, Ph, MBA, of ProScribe - Envision Pharma Group, and funded by Eli Lilly and Company.

\section{Availability of data and materials}

All data generated or analyzed during this study are included in this published article [and its supplementary information files].

\section{Ethics approval and consent to participate}

Not applicable.

\section{Consent for publication}

\section{Not applicable.}

\section{Competing interests}

The authors declared the following potential conflicts of interest with respect to the research, authorship, and/or publication of this article: TTa reports grants and personal fees from AbbVie, Asahi Kasei, Amgen Astellas BioPharma, Bayer Yakuhin, Daiichi Sankyo, Eisai Co. Ltd., Eli Lilly Japan, FUJIFILM Toyama Chemical Co. Ltd., Kowa Pharmaceuticals, Janssen Pharmaceutic, Kyowa Hakko Kirin, Mitsubishi Tanabe Pharma, Ono Pharmaceutical Co. Ltd., Otsuka Pharmaceutical Co. Ltd., Pfizer, Sawai Pharmaceutical Co. Ltd., and Takeda Pharmaceutical Co. Ltd. for speaker and consulting services unrelated to this publication. QW has no conflicts of interest to declare. KU, MK, YZ, NR, and TTr are employees of Eli Lilly and Company. Tr is a minor Eli Lilly shareholder. SS is an employee of ProScribe - Envision Pharma Group, a company that was funded by Eli Lilly and Company to provide medical writing support for this publication.

\section{Author details}

'Department of Neurology, Headache Center, Tominaga Hospital, Osaka, Japan. ${ }^{2}$ Department of Neurology, Jiangsu Province Hospital, Nanjing, China. ${ }^{3}$ Eli Lilly and Company, Shanghai, China. ${ }^{4}$ Medicine Development Unit-Japan, Eli Lilly Japan K.K., 5-1-28, Isogamidori, chuo-ku, Kobe 651-0086, Japan. ${ }^{5}$ ProScribe Envision Pharma Group, Sydney, Australia. ${ }^{6}$ Eli Lilly Australia Pty. Ltd., Sydney, Australia. ${ }^{7}$ GPORWE International, Lilly Hungaria Kft, Budapest, Hungary.

Received: 15 August 2019 Accepted: 28 November 2019 1.

\section{References}

1. Blumenfeld AM, Varon SF, Wilcox TK, Buse DC, Kawata AK, Manack A et al (2011) Disability, HRQoL and resource use among chronic and episodic migraineurs: results from the International Burden of Migraine Study (IBMS). Cephalalgia 31(3):301-315

2. Bonafede M, Sapra S, Shah N, Tepper S, Cappell K, Desai P (2018) Direct and indirect healthcare resource utilization and costs among migraine patients in the United States. Headache 58(5):700-714

3. Burch R, Rizzoli P, Loder E (2018) The prevalence and impact of migraine and severe headache in the United States: figures and trends from government health studies. Headache. 58(4):496-505

4. Buse DC, Manack AN, Fanning KM, Serrano D, Reed ML, Turkel CC et al (2012) Chronic migraine prevalence, disability, and sociodemographic factors: results from the American Migraine Prevalence and Prevention study. Headache. 52(10):1456-1470

5. Lanteri-Minet M (2014) Economic burden and costs of chronic migraine. Curr Pain Headache Rep 18(1):385

6. GBD 2016 Headache Collaborators (2018) Global, regional, and national burden of migraine and tension-type headache, 1990-2016: a systematic analysis for the Global Burden of Disease Study 2016. Lancet Neurol 17(11): 954-976

7. Martelletti P, Schwedt TJ, Lanteri-Minet M, Quintana R, Carboni V, Diener HC et al (2018) My Migraine Voice survey: a global study of disease burden among individuals with migraine for whom preventive treatments have failed. J Headache Pain. 19(1):115

8. Steiner TJ, Stovner LJ, Birbeck GL (2013) Migraine: the seventh disabler. Cephalalgia. 33(5):289-290

9. Leonardi M, Raggi A (2019) A narrative review on the burden of migraine: when the burden is the impact on people's life. J Headache Pain. 20(1):41

10. GBD 2016 Disease and Injury Incidence and Prevalence Collaborators (2017) Global, regional, and national incidence, prevalence, and years lived with disability for 328 diseases and injuries for 195 countries, 1990-2016: a systematic analysis for the Global Burden of Disease Study 2016. Lancet 390(10100):1211-1259

11. GBD 2015 Neurological Disorders Collaborator Group (2017) Global, regional, and national burden of neurological disorders during 1990-2015: a systematic analysis for the Global Burden of Disease Study 2015. Lancet Neurol 16(11):877-897

12. Buse DC, Lipton RB (2013) Global perspectives on the burden of episodic and chronic migraine. Cephalalgia. 33(11):885-890

13. Audulv $\AA$, Packer T, Versnel J (2014) Identifying gaps in knowledge: a map of the qualitative literature concerning life with a neurological condition. Chronic IIIn 10(3):192-243

14. Wöber-Bingöl C (2013) Epidemiology of migraine and headache in children and adolescents. Curr Pain Headache Rep 17(6):341

15. Mossey JM (2011) Defining racial and ethnic disparities in pain management. Clin Orthop Relat Res 469(7):1859-1870

16. Peng KP, Wang SJ (2014) Epidemiology of headache disorders in the AsiaPacific region. Headache. 54(4):610-618

17. Stark RJ, Ravishankar K, Siow HC, Lee KS, Pepperle R, Wang SJ (2013) Chronic migraine and chronic daily headache in the Asia-Pacific region: a systematic review. Cephalalgia. 33(4):266-283

18. International Headache Society. ICHD / Guidelines 2013 [Available from: http://www.ihs-headache.org/ichd-guidelines]] 
19. Gu X, Xie Y (2018) Migraine attacks among medical students in Soochow University, Southeast China: a cross-sectional study. J Pain Res 11:771-781

20. Huang GB, Yao LT, Hou JX, Zhang ZJ, Xin YT, Wu XY et al (2013) Epidemiology of migraine in the She ethnic minority group in Fujian province. China Neurol Res 35(7):684-692

21. Jin Z, Shi L, Wang YJ, Yang LG, Shi YH, Shen LW et al (2013) Prevalence of headache among children and adolescents in Shanghai, China. J Clin Neurosci 20(1):117-121

22. Li X, Zhou J, Tan G, Wang Y, Ran L, Chen L (2012) Diagnosis and treatment status of migraine: a clinic-based study in China. J Neurol Sci 315(1-2):89-92

23. Lin QF, Xia QQ, Zeng YL, Wu XY, Ye LF, Yao LT et al (2018) Prevalence of migraine in Han Chinese of Fujian province: an epidemiological study. Medicine (Baltimore) 97(52):e13500

24. Liu R, Yu S, He M, Zhao G, Yang X, Qiao X et al (2013) Health-care utilization for primary headache disorders in China: a population-based door-to-door survey. J Headache Pain. 14:47

25. Luo N, Qi W, Tong W, Tan F, Zhang Q, He J et al (2014) Prevalence and burden of headache disorders in two neighboring provinces of China. J Clin Neurosci 21(10):1750-1754

26. Wang $X$, Sun J, Xing Y, Zhou H, Zhao Y, Zhu Y (2015) The prevalence and awareness of migraine among university students in Harbin, China. J Oral Facial Pain Headache 29(4):384-389

27. Wang $X$, Xing Y, Sun J, Zhou H, Yu H, Zhao $Y$ et al (2016) Prevalence, associated factors, and impact on quality of life of migraine in a community in Northeast China. J Oral Facial Pain Headache 30(2):139-149

28. Wang Y, Zhou J, Fan X, Li X, Ran L, Tan G et al (2011) Classification and clinical features of headache patients: an outpatient clinic study from China. $J$ Headache Pain 12(5):561-567

29. Yu S, Liu R, Zhao G, Yang X, Qiao X, Feng J et al (2012) The prevalence and burden of primary headaches in China: a population-based door-to-door survey. Headache 52(4):582-591

30. Zhang Y, Shi Z, Hock D, Yue W, Liu S, Zhang Y et al (2016) Prevalence of primary headache disorders in a population aged 60 years and older in a rural area of Northern China. J Headache Pain. 17(1):83

31. Kong CK, Cheng WW, Wong LY (2001) Epidemiology of headache in Hong Kong primary-level schoolchildren: questionnaire study. Hong Kong Med J 7(1):29-33

32. Wong TW, Wong KS, Yu TS, Kay R (1995) Prevalence of migraine and other headaches in Hong Kong. Neuroepidemiology. 14(2):82-91

33. Fuh JL, Wang SJ, Lu SR (2008) Impact of migraine on the employed labor force in Taiwan. J Chin Med Assoc 71(2):74-78

34. Hung PH, Fuh JL, Wang SJ (2006) Validity, reliability and application of the Taiwan version of the migraine disability assessment questionnaire. J Formos Med Assoc 105(7):563-568

35. Lu SR, Fuh JL, Chen WT, Juang KD, Wang SJ (2001) Chronic daily headache in Taipei, Taiwan: prevalence, follow-up and outcome predictors. Cephalalgia. 21(10):980-986

36. Lu SR, Fuh JL, Juang KD, Wang SJ (2000) Migraine prevalence in adolescents aged 13-15: a student population-based study in Taiwan. Cephalalgia. 20(5): 479-485

37. Lu SR, Wang SJ, Fuh JL (2006) The practice pattern of migraine management among neurologists in Taiwan. Cephalalgia. 26(3):310-313

38. Tang CH, Chen YC, Ng K, Wang SJ (2013) A retrospective matched casecontrol study on medical costs of refractory migraine in Taiwan. Headache. 53(3):526-539

39. Wang SJ, Fuh JL, Huang SY, Yang SS, Wu ZA, Hsu CH et al (2008) Diagnosis and development of screening items for migraine in neurological practice in Taiwan. J Formos Med Assoc 107(6):485-494

40. Wang SJ, Fuh JL, Juang KD, Lu SR (2005) Rising prevalence of migraine in Taiwanese adolescents aged 13-15 years. Cephalalgia. 25(6):433-438

41. Wang SJ, Fuh JL, Juang KD, Lu SR (2009) Migraine and suicidal ideation in adolescents aged 13 to 15 years. Neurology. 72(13):1146-1152

42. Wang SJ, Fuh JL, Lu SR, Juang KD (2001) Quality of life differs among headache diagnoses: analysis of SF-36 survey in 901 headache patients. Pain. 89(2-3):285-292

43. Wang SJ, Fuh JL, Young YH, Lu SR, Shia BC (2000) Prevalence of migraine in Taipei, Taiwan: a population-based survey. Cephalalgia 20(6):566-572
44. Wang SJ, Fuh JL, Young YH, Lu SR, Shia BC (2001) Frequency and predictors of physician consultations for headache. Cephalalgia 21(1):25-30

45. Wang SJ, Liu HC, Fuh JL, Liu CY, Lin KP, Chen HM et al (1997) Prevalence of headaches in a Chinese elderly population in Kinmen: age and gender effect and cross-cultural comparisons. Neurology. 49(1):195-200

46. Wang SJ, Wang PJ, Fuh JL, Peng KP, Ng K (2013) Comparisons of disability, quality of life, and resource use between chronic and episodic migraineurs: a clinic-based study in Taiwan. Cephalalgia 33(3):171-181

47. Ando N, Fujimoto S, Ishikawa T, Teramoto J, Kobayashi S, Hattori A et al (2007) Prevalence and features of migraine in Japanese junior high school students aged 12-15 yr. Brain Dev 29(8):482-485

48. Goto M, Yokoyama K, Nozaki Y, Itoh K, Kawamata R, Matsumoto S et al (2017) Characteristics of headaches in Japanese elementary and junior high school students: a school-based questionnaire survey. Brain Dev 39(9):791798

49. ligaya M, Sakai F, Kolodner KB, Lipton RB, Stewart WF (2003) Reliability and validity of the Japanese Migraine Disability Assessment (MIDAS) Questionnaire. Headache. 43(4):343-352

50. Kotani K, Shimomura T, Ikawa S, Sakane N, Ishimaru Y, Adachi S (2004) Japanese with headache: suffering in silence. Headache 44(1):108-109

51. Sakai F, Igarashi H (1997) Prevalence of migraine in Japan: a nationwide survey. Cephalalgia 17(1):15-22

52. Suzuki N, Ishikawa Y, Gomi S, Ito N, Watanabe S, Yokoyama M et al (2014) Prevalence and characteristics of headaches in a socially active population working in the Tokyo metropolitan area -surveillance by an industrial health consortium. Intern Med 53(7):683-689

53. Takeshima T, Ishizaki K, Fukuhara Y, ljiri T, Kusumi M, Wakutani Y et al (2004) Population-based door-to-door survey of migraine in Japan: the Daisen study. Headache. 44(1):8-19

54. Choi YJ, Kim BK, Chung PW, Lee MJ, Park JW, Chu MK et al (2018) Impact of cluster headache on employment status and job burden: a prospective cross-sectional multicenter study. J Headache Pain. 19(1):78

55. Chu MK, Kim DW, Kim BK, Kim JM, Jang TW, Park JW et al (2013) Genderspecific influence of socioeconomic status on the prevalence of migraine and tension-type headache: the results from the Korean headache survey. J Headache Pain 14:82

56. Kim BK, Chu MK, Lee TG, Kim JM, Chung CS, Lee KS (2012) Prevalence and impact of migraine and tension-type headache in Korea. J Clin Neurol 8(3):204-211

57. Kim BK, Chung YK, Kim JM, Lee KS, Chu MK (2013) Prevalence, clinical characteristics and disability of migraine and probable migraine: a nationwide population-based survey in Korea. Cephalalgia. 33(13):1106-1116

58. Rho Yl, Chung HJ, Lee KH, Eun BL, Eun SH, Nam SO et al (2012) Prevalence and clinical characteristics of primary headaches among school children in South Korea: a nationwide survey. Headache 52(4):592-599

59. Roh JK, Kim JS, Ahn YO (1998) Epidemiologic and clinical characteristics of migraine and tension-type headache in Korea. Headache. 38(5):356-365

60. Yu S, Zhang Y, Yao Y, Cao H, Yu N, Liu Q (2019) Treatment patterns and health care expenditures in patients with migraine: results from China Health Insurance Research Association (CHIRA) database [poster presentation]. International Headache Congress (IHC), Dublin, Ireland; September 5th-8th, 2019

61. Ueda K, Ye W, Lombard L, Kuga A, Kim Y, Cotton S et al (2019) Real-world treatment patterns and patient-reported outcomes in episodic and chronic migraine in Japan: analysis of data from the Adelphi migraine disease specific programme. J Headache Pain 20(1):68

62. Meyers $J$, Davis KL, Lenz RA, Sakai F, Xue F (2019) Treatment patterns and characteristics of patients with migraine in Japan: a retrospective analysis of health insurance claims data. Cephalalgia. 39(12):1518-1534

63. Arai YC, Yasui H, Isai H, Kawai T, Nishihara M, Sato J et al (2014) The review of innovative integration of Kampo medicine and Western medicine as personalized medicine at the first multidisciplinary pain center in Japan. EPMA J 5(1):10

64. Ahn CB, Lee SJ, Lee JC, Fossion JP, Sant'Ana A (2011) A clinical pilot study comparing traditional acupuncture to combined acupuncture for treating headache, trigeminal neuralgia and retro-auricular pain in facial palsy. J Acupunct Meridian Stud 4(1):29-43

65. Vo P, Fang J, Bilitou A, Laflamme AK, Gupta S (2018) Patients' perspective on the burden of migraine in Europe: a cross-sectional analysis of survey data in France, Germany, Italy, Spain, and the United Kingdom. J Headache Pain. 19(1):82 
66. Messali A, Sanderson JC, Blumenfeld AM, Goadsby PJ, Buse DC, Varon SF et al (2016) Direct and indirect costs of chronic and episodic migraine in the United States: a web-based survey. Headache. 56(2):306-322

67. Bloudek LM, Stokes M, Buse DC, Wilcox TK, Lipton RB, Goadsby PJ et al

(2012) Cost of healthcare for patients with migraine in five European countries: results from the international burden of migraine study (IBMS). J Headache Pain. 13(5):361-378

68. The Japanese Headache Society. Lifting the burden: global compaign to reduce the burden of headache worldwide. Kyoto Declaration on Headache 2005 [Available from: http://www.jhsnet.org/pdf/kyoto2005.pdf]]

\section{Publisher's Note}

Springer Nature remains neutral with regard to jurisdictional claims in published maps and institutional affiliations.

Ready to submit your research? Choose BMC and benefit from:

- fast, convenient online submission

- thorough peer review by experienced researchers in your field

- rapid publication on acceptance

- support for research data, including large and complex data types

- gold Open Access which fosters wider collaboration and increased citations

- maximum visibility for your research: over $100 \mathrm{M}$ website views per year

At $\mathrm{BMC}$, research is always in progress.

Learn more biomedcentral.com/submissions 